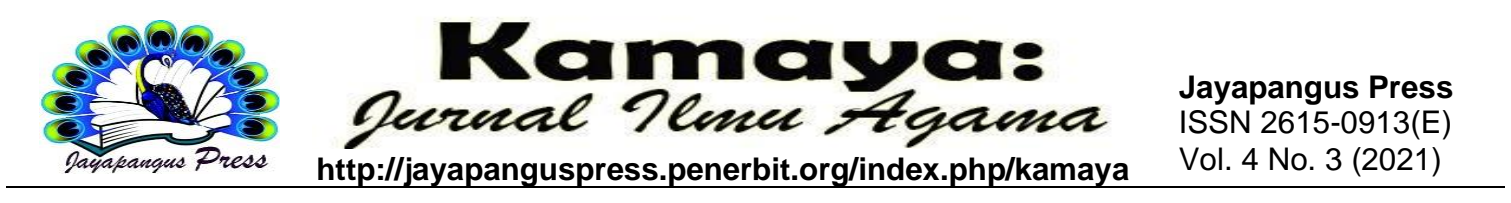

\title{
Hinduism Teachings in the Story of Ni Diah Tantri
}

\author{
I Made Luwih ${ }^{1}$, I Ketut Sudarsana ${ }^{2}$ \\ ${ }^{12}$ Universitas Hindu Negeri I Gusti Bagus Sugriwa Denpasar \\ 1imadeluwih@uhnsugriwa.ac.id, ${ }^{2}$ iketutsudarsana@uhnsugriwa.ac.id
}

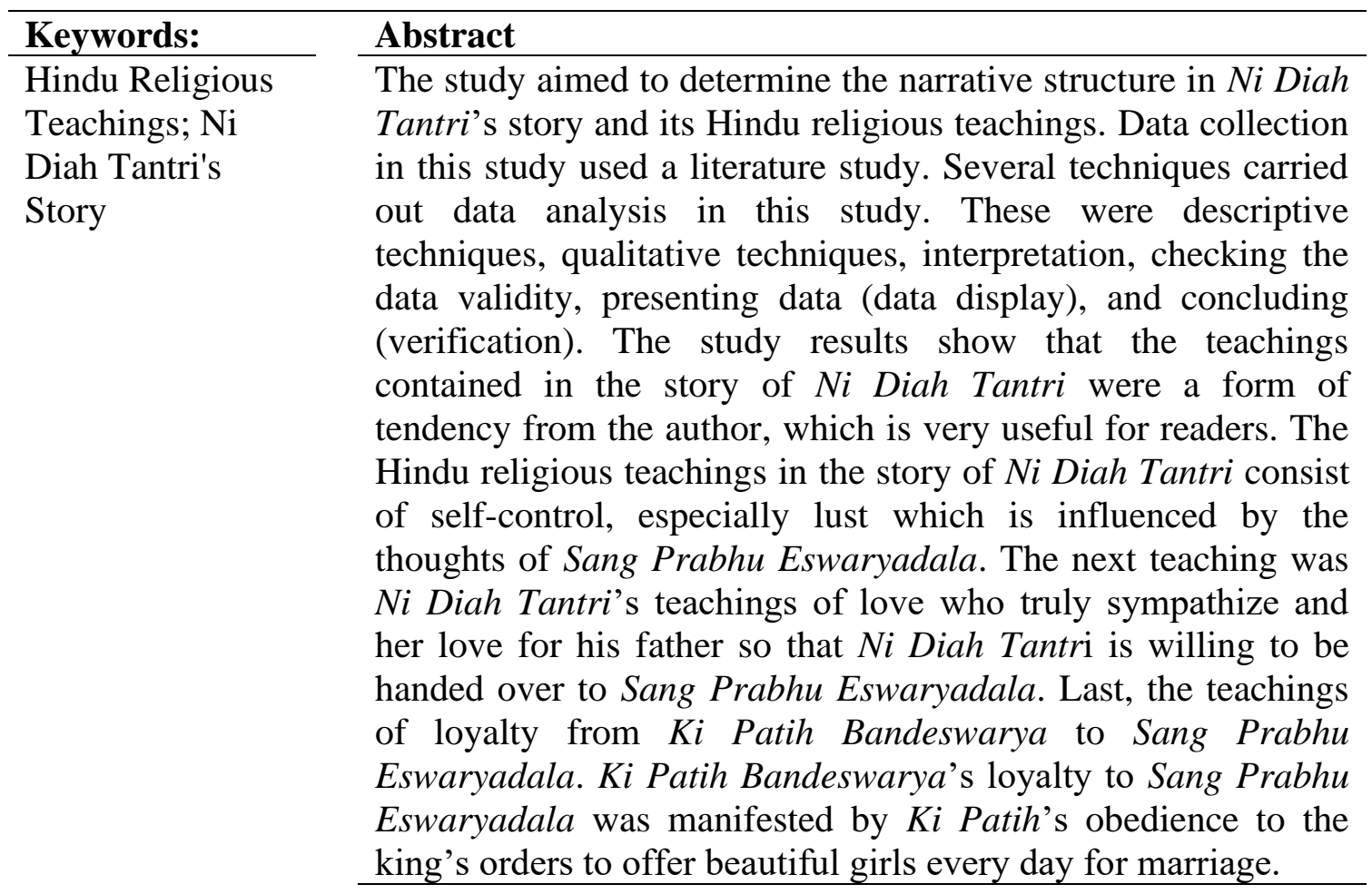

Kata Kunci:

Ajaran Agama

Hindu; Cerita Ni

Diah Tantri

\begin{abstract}
Abstrak
Penelitian cerita Ni Diah Tantri bertujuan untuk mengetahui struktur naratif dalam cerita Ni Diah Tantri serta ajaran agama Hindu yang terkandung dalam cerita Ni Diah Tantri. Pengumpulan data pada penelitian ini menggunakan studi kepustakaan. Analisa data dilakukan teknik deskriptif, teknik kualitatif, interpretasi, pengecekan kesahihan data, penyajian data (display data) dan penarikan kesimpulan (verifikasi). Hasil penelitian menunjukkan ajaran yang terkandung dalam cerita Ni Diah Tantri merupakan bentuk tendensi dari pengarang yang sangat bermanfaat bagi pembaca. Ajaran agama Hindu dalam cerita Ni Diah Tantri terdiri dari pengendalian diri, terutama nafsu yang dipengaruhi oleh pikiran Sang Prabhu Eswaryadala. Ajaran berikutnya adalah ajaran cinta kasih seorang Ni Diah Tantri benar-benar menaruh simpati dan memiliki rasa cinta kasih kepada ayahnya sehingga Ni Diah Tantri rela diserahkan kepada Sang
\end{abstract}


Prabhu Eswaryadala. Terakhir ajaran kesetian dari Ki Patih Bandeswarya kepada Sang Prabhu Eswaryadala. Kesetiaan Ki Patih Bandeswarya kepada Sang Prabhu Eswaryadala diwujudkan dengan kepatuhan Ki Patih terhadap perintah sang raja untuk mempersembahkan gadis cantik setiap harinya untuk dinikahi.

\section{Introduction}

Nowadays, the condition of society has changed and faced with very complex problems. The problems that occur include economic, political, ideological, social, and cultural problems that can lead to a moral decline in the community. It is proven by many societal conflicts with ethnic, racial, and religious nuances. Balinese society has transformed from an integrative, cosmological, religious-religious agrarian to an individualism, materialism, profane, and secularization industrial society characterization (Suweta, 1999). In the transformation period, society normatively bound by Hindu religious teachings, then will face modernization teachings dominated by materialistic elements.

The globalization era is full of foreign influences due to advances in science and technology. Thus, it will influence various aspects of people's lives, especially Bali. Responding to this influence, it seems necessary to have cultural resilience through character education and the strength and determination of sraddha and bhakti service. Cultural resilience includes the extent to which people develop their cultural teachings. By having the strength and determination of sraddha and bhakti service, people are always trying to harmonize and balance physical and spiritual, material and spiritual demands based on the conception of religious teachings and character education. Maintaining culture through character education is a challenge for society in the future. Character education is an essential and integral part of human life through the form of culture developed in the community in providing lessons through character education. Through knowledge, we will sort and choose a true culture according to our minds. Moreover, character education is based on religious teachings.

The Hindu religious teaching is expected to filter out foreign cultures that develop and have a terrible impact on the behavior of people in Bali. Culture is the work of humans who have Hindu religious teachings to play their role in people's lives in Bali. The story of Ni Diah Tantri is one of the cultural products that describes the Hindu religious teaching in the formation of one's character through the story of Ni Diah Tantri. The importance of Ni Diah Tantri's story being developed in character 
education as a development of understanding of the story in shaping virtuous behavior (Hutomo, 1991).

The development of the Ni Diah Tantri story is well known in Bali and was copied into book form according to the story of Kekawin Tantri, Kidung Tantri Nandhaka-harana, Mandhuka-prakarana, Kidung Ragawinasa, Kidung Pisaca-harana, Parikan Tantri, Guguritan Cangak, Geguritan Panca Puspita, Tantri Kamandaka, and Tantri Prasi. The story of Ni Diah Tantri is a literary work in prose told by I Made Pasek in Balinese which is derived from the story of Kidung Tantri Nandhaka Harana. According to Lontar Tantri Kamandaka, Tantri stories can be divided into three parts, namely Tantri Nandhaka Prakarana, Mandhuka Prakarana, and Pisaca Prakarana. First, Kidung Tantri Nandhaka-harana was composed by Ida Pedanda Nyoman Pidada with Ida Pedanda Ketut Pidada in the caka year 1630 or 1728 AD. Second, Kidung Tantri Mandhuka-Prakarana was composed by I Gusti Made Tangeb from Sidemen Village, Karangasem. The third Tantri story is Kidung Tantri Pisaca-harana composed by Ida Pedanda Gede Sidemen from Griya Intaran Sanur in the caka year 1860-1866 or 1938-1944 AD.

The grouping of Tantri stories above as literary works was rewritten by I Made Pasek using the Balinese language, published in 1837 or 1915 AD and re-published by Parisada Hindu Dharma Center in 1976 retells the Kidung Tantri Nandhaka-harana. After Kidung Tantri Nandhaka-harana's publication in 1976, the Dharma Sastra Foundation published a book entitled Tantri Stories by Pasek (2006) which tells of $N i$ Diah Tantri with Sang Prabhu Eswaryadala with the first printing in 1999. The second was in 2006 consisted of one chapter, namely a Tantri story with 24 subtitles. It is a story told by Ni Diah Tantri to Sang Prabhu Eswaryadala at bedtime.

Based on the explanation above, the researcher considers it necessary to study the Ni Diah Tantri story, which contains Hindu religious teachings that are still relevant in the current era because substantially, they are still used as a way of life by the community. There are two different sides of good and bad in the characterization of $\mathrm{Ni}$ Diah Tantri story in providing an understanding of behavior based on the character education. 


\section{Method}

The type of study was descriptive qualitative research. Qualitative research is a research procedure that produces descriptive data in speech or writing and the observed people's behavior. In this study, the researchers tried to identify the subjects and share what they experienced in their daily lives. Data sources could be divided into two types, namely primary data and secondary data. The primary data used in this study was the story of Ni Diah Tantri as the source data preparation of scientific papers. Meanwhile, the secondary data included supporting data obtained through other references in books and documents to help solve the study problem. Therefore, this study presented primary and secondary data, where the main data came from the story of Ni Diah Tantri. Data collection in this study using literature study. Data analysis was carried out by descriptive techniques, qualitative techniques, interpretation, checking the data validity, presenting data (data display), and concluding (verification).

\section{Results and Discussions}

The Hindu religious teachings have a very close relationship with morality, which comes from two syllables, namely su and sila. $S u$ means good, and sila means good habits or human behavior (Suhardana, 2007). Therefore, ethics is a science that studies the teaching system, about the good and bad of an action, what to do or to avoid in character education, to create a good relationship between fellow human beings. Ethics itself is good behavior or actions, which are usually called sila. Therefore, the science is called the science of sila or tata susila. One aspect of character education is discussing the moral aspect and the meaning of what is good and bad. Character is selfcontrol, love, and loyalty that someone who receives character education is because he loves himself and respects others. Thus, it is not selfish but humanistic (Suhardana, 2007). Through character education, a sense of togetherness and self-worth will determine the dissemination and deepening of ethical teachings realized in the community. Character education aims to improve human status from a lower to a higher level. The process of improvement cannot occur without experiencing a gradual process. Thus, there is a gradual or tiered improvement process until it reaches the highest purpose in carrying out religious teachings.

Rumaga Ida Ni Diah Tantri, mawinan tan patanding yan buat kaayuan. Wiakti luir tan wenten ring Rate arsanida Sang Prabhu Eswaryadala, seemper ring Suralaya (Pasek, 2006). 
Translation:

She is Ni Diah Tantri because there is no match for her beauty. It is really good not to be in the world of her feelings, Sang Prabhu Eswaryadala is floating in Heaven.

Based on the quotation above, one of the basic principles in character education is based on religious norms. Thus, it is not just the ethics of outward appearance as etiquette, but it guides people to have a noble character. Therefore, it can achieve a happy, safe, and peaceful life, a harmonious relationship physically and mentally between humans and humans, humans and their environment, and a harmonious relationship between humans and Ida Sang Hyang Widhi Wasa. Therefore, character education in Ni Diah Tantri's story is expected to create good families and community members, become sons of the nation and human beings with noble personalities and guide them to achieve happiness. Therefore, the developed and told Ni Diah Tantri story always motivates to have a Tat Twam Asi personality. In addition, Tat Twam Asi is the basis of character education in good and noble behavior.

Based on the understanding of Tri Kaya Parisudha, which is the basis in carrying out life behaviors for the safety of the living world in society. Tri Kaya Parisudha explained the character education through Hindu religious teachings that can divide into three major groups, namely as follows.

1. Samaniya Dharmaśāstra or Nitya Dharmaśāstra is a universally applicable ethic. It means that it applies to everyone and is usually carried out in everyday life. Rules of conduct or ethics must follow in daily practice, and some must avoid. What must be followed are various good and exemplary codes of conduct, while what must avoid is bad or contrary ethics to religious teachings. The good ethics or behaviors that Hindus should follow are as follows. These are Catur Marga or Catur Yoga, Tri Kaya Parisudha, Yama Niyama Brata, Daśa Dharma, Catur Purusaārtha, Catur Pāramitha, Tri Hita Karana, Asta Brata, Sad Mitra, Sad Guna, Asada Brata, Daśa Indria, Catur Aiswarya, Sad Pāramitha, Asataa Siddhi, Daśa Paramārtha, Tri Brata, Tri Karana/Tri Sādhana, Daśa Sila, Tri Parārtha. Meanwhile, bad ethics or behavior that Hindus should avoid are as follows. These are Tri Mala, Tri Mala Paksaa, Sapta Timira, Sad Atatayi, Sad Ripu, Daśa Mala, Catur Pataka, Pañca Bahya Tusti, Asataa Dusta, Asataa Cora. 
2. Naimitika Dharmaśāstra is an ethic that applies to matters of a special nature and applies in a limited environment. In addition, Naimitika Dharmaśāstra exists because humans have differences, such as gender, age, occupation, hobbies, etc. That is why each community group has its moral system, which cannot be applied to other groups. For example, each architect/undagi has its own rules, and the management of rice fields for each village has its provisions, and so on.

3. Kamya Dharmaśāsastra is a mandatory rule of behaviors. It usually applies to yajña activities, including ceremonies and offerings (upakara). In this case, what has been determined absolutely must be followed. It means that it is not negotiable, such as the time or good days (pedewasaan) of the ceremony, the place of the ceremony, the type of offering or ceremony, and so on. Examples of this Kamya Dharmaśāsastra is the Pañca Yajña which includes Dewa Yajña, Resi Yajña, Pitra Yajña, Manusa Yajña, and Bhūta Yajña. Kamya Dharmaśāsastra includes prayer (sembah bhakti), Brata Penyepian, Brata Sāraswatī (Suhardana (2007).

Based on the quotation explanation above, the Hindu religious teachings that will be analyzed in the story of Ni Diah Tantri are a harmonious behavior level with humans, the environment, and God. Thus, all human behaviors must be based on Dharma. In addition, it is also based on wiwekajnana to distinguish which actions should be followed and avoided. Therefore, if everything has been obtained by doing Dharma, it was outlined by Hindu religious teachings.

\section{The Teaching of Self-Control}

Before discussing the self-control teachings contained in the story of Ni Diah Tantri, it will briefly discuss the meaning of self-control from several experts.

According to Sura (1995), self-control is ethics in the association of living together. Humans are homo socius or friendly creatures. Humans cannot live alone and always together with other people. Humans can only live as well as possible, and humans will only have meaning if they live together with other humans in society.

According to Aryasa (1996), self-control implies order. Thus, if it relates in a practical sense, self-control is an orderly attitude according to the measures of conscience and applicable norms.

The story of Ni Diah Tantri describes noble deeds and behaviors to teach someone to control themselves, especially lust which is influenced by the mind. Ni Diah Tantri teaches through stories to behave based on the teachings of Trikaya Parisudha, 
namely the three good deeds, which consist of manacika, wacika, and kayika, which means thinking, saying, and doing good. Based on the characterization, Ni Diah Tantri's character teaches self-control teachings to Maharaja Sang Prabhu Eswaryadala. Therefore, Maharaja Sang Prabhu Eswaryadala was able to respond to the advice of Ni Diah Tantri, which can see in the following quotation.

Ne mangkin nenten wenten anak mawarna jegeg keaaksi, sakewenten asiki, $\mathrm{Ni}$

Diah Tantri dreman listu ayu. Munggwing pamarganida Sang Prabhu Eswaryadala sane sampun-sampun, tan mari ngamong pawestri. Sane mangkin tan maren ida duleg ring pakayunan, nyingak para wanitane (Pasek, 2006).

Translation:

There are no more beautiful women now, only one, the beloved and very beautiful Ni Diah Tantri. Because of what Prabhu Eswaryadala had done before, he always wanted to get married. And now he always feels jealous, looking at the women.

Due to the lack of self-control of Prabhu Eswaryadala until he gets married to the girl in his kingdom. Thus, self-control is significant in human life. The importance of self-control in Sarasamuscaya 315 (Sudra, 1995) is as follows.

Pratyaham pratyarekseta hyatmano vrittam atmana

Kinnu me pasubhistulyam kinnu satpurusaih samam

Matangnyam haywa tan pawiweka, awakta

Ta pwa Umangen-angen ulahny awakta

Sari, linganta, salah kariki ulahta

Yukti karika, pada lawan pasu kariki

Ta mangke, pada lawan sang pandita

Kunang, deniki prawrttinta, mangkana

Lingata sari yatna tutura ri prawrttinta

Translation:

Therefore, it should not be without consideration or investigation, but you should think about your daily behaviors. You think, "is one of my behaviors is true or not; is it the same as the animal or the same as the Pandita is my behavior?". Thus, your thoughts from day to day, and you always advise yourself about your actions. 
Humans behave during their lives on two different paths. These two different behaviors are commonly called good and bad deeds. Subha and Asubha Karma are good and bad of human behaviors. As the highest beings who have creativity, taste, and intention, humans must be able to use their self-control in deciding between good and bad deeds, right and wrong. Humans can control themselves by referring to their three abilities: thinking, saying, and acting.

Humans have abilities that are subject to the law of Rwa Bhineda (two different things), so its ability should be directed to Subha Karma (good deeds). Although it realizes that Subha Karma is good behavior in daily life, bad deeds often drag humans down. Therefore, if Subha Karma is the target of thoughts, words, and actions, then the abilities that exist in humans will be transformed into good and right behavior. Based on the description above, it can explain that the author of Ni Diah Tantri's story wants to convey self-control teachings through his work.

Self-control is the happiness and suffering of other beings, defined as Tat Twam Asi. Likewise, torturing others means torturing oneself. Thus, people who can carry out the teachings of Tat Twam Asi will arise a sense of togetherness in their hearts while enjoying the happiness and suffering felt by others. It must start from understanding the Trikaya Parisudha teaching concepts to foster deep affection. It is three elements of self-control that start from Manacika (control of the mind), Wacika (control of speech), and Kayika (control of actions). If people can achieve these three elements of selfcontrol, they will find true happiness (Sangka, 1998).

The form of self-control in the association of living together in the story of $\mathrm{Ni}$ Diah Tantri is a reflection of humans with noble character. Through the story of $\mathrm{Ni}$ Diah Tantri, humans are taught to be friends, cannot be alone, and are always together with others. Humans can only live as well as possible, and humans will have meaning if they live together with other humans in society. From they are born to death, humans need other people for the perfection of their life. Therefore, help from humans is not only through help to meet spiritual needs. Ni Diah Tantri's story describes that humans need understanding, love, mutual respect, recognition, and emotional responses, which are very important for association and survival, to influence other people.

All human needs are spiritual needs that can only be obtained in relation to other humans in society. Thus, human nature is a social creature in relation to other people, not in solitude. Therefore, people have to regulate themselves to behave in everyday 
life. Humans must adjust and control themselves against actions that can harm other humans and their environment and obey the norms' rules. Ni Diah Tantri's story reinforces character education to reach the realm of freedom because deeds or guidelines based on ethics can manifest the characteristics of a sacred inner practice. Therefore, be ethical with inner purity so that acts in behavior occur with sincerity.

\section{The Teaching of Love (Karuna)}

Love or affection is an act that can accept loving oneself and respecting others. Thus, it is not selfish but humanistic (Suhardana, 2007).

Purwodarminto (2000), in the Indonesian Dictionary, explains that love is defined by feelings of affection, feelings of love, or feelings of liking for someone. Therefore, the form of love is a condition of being loving and being loved. We can see in a family, if we lose one aspect of love, for example, the aspect of responsibility, then the unity of the household is broken. Love that unaccompanied by honesty will threaten the household happiness. According to Sangka (1998: 120), love is the basis of all virtues and decency. Therefore, it should be developed through a deep sense of love and affection to cultivate solid decency. Everyone is expected to be able to give love and affection to others and love themselves. Therefore, the teachings of Tat Twam Asi can be used as basic guidelines in ethical behavior, helping each other, respecting each other, tolerance, and being willing to sacrifice.

Character education cannot be separated from religious education, especially Hinduism. Love in Hinduism is called Bhakti. Bhakti is purifying the mind by exalting His greatness and avoiding despicable actions. It is used to express love for something higher or respected. Bhakti can be divided into two parts, namely Aparabhakti and Para Bhakti (Sukartha, 2003).

Aparabhakti is loving-kindness whose manifestation is still lower and is practiced by those who do not yet have a high level of holiness. While Para Bhakti is love in its higher manifestation and can be practiced by people whose has high jñana and their sanctity has increased. The teaching of Bhakti is direct and real teaching to seek God, natural teaching, readily accepted and implemented by ordinary people. The teachings from the beginning, the middle, and the end continue to move in the vibration of love. The teaching of Bhakti is easily implemented teaching by all levels and human nature, both the poor, merchants, rich people, government officials, intelligent people, 
and lack of knowledge. Therefore, devoted people immediately enjoy the results of religion, where love is the instrument and affection for God.

For a bhakta, they do not need to know whether God is good or bad, small or big, powerful or not. What matters to them is that God is loved. A Bhakta people love God not because he wants to be rewarded for entering heaven or Moksha, because giving affection to God is the highest happiness. Bhakti/Bhakta marga use taste as a means. A natural but overflowing love taste, a love that flows like a river that moves to rush because it longs to meet the ocean. It looks like weak vines that faithfully watch the excellent work from the bottom to the top. So likewise, a Bhakti who is attached to God never leaves himself for a moment. Even though ordinary people do not know anything, their devotion (Bhakti) unites them with God.

Kakawin Arjunawiwaha VI.4 (in Wiryamartana, 1990: 135) explains that besides devotion to God, relatives, ancestors, Arjuna truly loves his people. For the sake of love and devotion, Sang Arjuna meditated on Mount Indrakila with various temptations and trials. These temptations were seven beautiful nymphs who tempt Arjuna, but he did not waver in the slightest. Then, he was tested by Dewa Indra, disguised as an old hermit, and the dialogue took place. Sang Arjuna said he was sincere in meditating because of his love and devotion to his brother, Yudhisthira or Sang Dharmaputra. He wants to get the gift of Bhatara Siwa so that his ideals are victorious and powerful in the world, and he wants to do his service to maintain the whole world peaceful, safe, far from wrath. The purpose of Dewa Indra is to get a powerful human to fight Sang Niwatakawaca (a famous, powerful Danawa King who did not die by gods, yaksas, and asuras but only powerful humans need to be wary of). Kakawin Arjunawiwāha is explained as follows.

Sahur ira tan apañjang singgih śabda muniwara

Nghulun tiki katalyan de ning bhakti lawan asih

Ana pinaka kakangkwan śrī Dharmātmaja karĕngö

Sira ta pinatapākĕn mahyun digjaya wijaya (Arjunawiwāha VI.4).

Translation:

I am bound by bhakti and love

I have a brother named Sang Dharmaputra

For him, I was meditating with the ideals of glory and power in the world. (Wiryamartana, 1990: 135). 
Based on the quotation above, humans are creatures created by God who can create a useful culture for their survival and has a good relationship with humans and their environment. So basically, the purpose of human life is to achieve liberation. It can only achieve through devotion (Bhakti), hard work, or doing good in this life. Only born as humans can we improve life level to reach the desired standard of living, namely moksha. Without going through life or birth, we cannot achieve perfection. Therefore, we must be grateful to be born as human beings who have a good opportunity to do good deeds so that we can live eternally one day. In this life, we can enjoy the teachings of sanctity that guide humanity to act based on legal and religious norms that they adhere to. Thus, the purpose of life is to do good which is the starting point for liberation. Character and affection education is a form of Dharma during life as human beings because only we can behave well. It is because humans can distinguish good things from bad. Life is considered a bridge, and one's success in using this bridge to be in heaven depends on applying Dharma. This statement implies the command with all its consequences, namely not to suffer the consequences and instead to be obeyed. Heaven is the reward.

The story of Ni Diah Tantri can be used as a guide in supporting life. Life as the main creature cannot separate from the basic guidelines of human life, namely as follows. a) work means human must work to meet the needs of his life based on Dharma as signs of life in this life, b) learning dharma or tattwa means as humans are always learning because it will never end as long as humans live so that they can be wise, carry out good deeds (śubhakarma) and avoid bad deeds (aśubhakarma), c) serving and being devoted means that human must be devoted to Ida Sang Hyang Widhi Wasa/God Almighty, ancestors or parents, and others so that there is harmony, balance in life to create a safe, and peaceful atmosphere, d) socializing positively, means that association determines everything. An example of wrong association is associating with criminals, which will be infected with the character. Therefore, humans must choose in association (Sukartha, Supartha, Sandiarta, Wiryani, 2003).

Mastering the teachings of love contained in the story of Ni Diah Tantri, then one should have the qualities of sattwam and control the nature of rajas and tamas. For example, steadfast in facing the trials of life full of joys and sorrows, diligent in doing a beneficial job for himself and many people without considering the gains and losses. In addition, human always donates (dania punia) to other people who need it, both 
materially and spiritually, always obediently studying sacred knowledge and devotional service, and other noble qualities that are very beneficial for himself and many people.

Sawusan ajine maridartayang punika, tumuli Ni Diah Tantri matur pinunas, mangda dane ka aturang ring Sang Prabhu Sri Heswaryadala (Pasek, 2006:3).

Translation:

After his father told this, Ni Diah Tantri pleaded, that she be handed over to Sang Prabhu Eswaryadala.

The quotation above proves that Ni Diah Tantri truly sympathized and has affection for her father. Thus, Ni Diah Tantri was willing to be handed over to Sang Prabhu Eswaryadala. Thus, the ethical behavior of Ni Diah Tantri is a reflection of and as a result of the influence of satwa characteristics. Preferably, every human behavior in everyday life that reflects the behavior of adharma is the reflection and influence of rajas and tamas. The characteristics of the influence of rajas and tamas are enemies that exist in the individual and the most dangerous enemies compared to enemies that come from outside. Internal enemies, such as laziness and envy, can plunge a person into a valley of suffering and misery. Realizing that these enemies are dangerous, it needs to be controlled to improve a better standard of living. Ni Diah Tantri's affection became a way to improve the bad qualities of Sang Prabhu Eswaryadala.

\section{The Teaching of Loyalty (Satya)}

The story of Ni Diah Tantri aims to provide an understanding for readers, especially Hindus, so that they can live based on teachings that contain loyalty. The teaching of loyalty is expected can foster self-confidence of the people, and they can practice and apply it in social life so that the community can trust it.

The teachings of yoga, Satya, or loyalty, are truth, and loyalty also means honesty. Therefore, everyone always demands honesty and kindness because these qualities will bring people to peace. If a person wants to manifest the divine qualities in himself, then Satya must be carried out seriously because God is the truth. One that only living in Satya is the one can do Satya. Since Satya is truth, it is only found through the truth. Satya brings humans to their divine nature, the nature of the truth within themselves (Sura, 1995).

Loyalty is something that everyone in the association must own, wherever they are and at any time. Even since the Vedic era, this teaching of loyalty has been known 
and has always echoed to this day 'satyam eva jayate nanrtam" which means that only truth wins, not untruth. Thus, loyalty is important in self-control for Hindus (Sangka, 1998).

Based on the explanation above, the teaching of loyalty in the story of Ni Diah Tantri was described by Ki Patih Bandeswarya to Sang Prabhu Eswaryadala. Ki Patih Bandeswarya realized the teachings of his loyalty through the king's order to offer a young and beautiful girl every day for his marriage. Ki Patih Bandeswarya's teachings of loyalty are quoted in the following story of Ni Diah Tantri.

Dane Ki Patih Bandeswarya ngiring sakadi pakarsanida Sang Prabhu Eswaryadala, nyabran-nyabran ngaturang wanita anom tur ayu adiri. Dening asapunika, kasuwen-suwen telas pare istrine ayu tur anom sampun katur (Pasek, 2006).

Translation:

Ki Patih Bandeswarya followed the words of the Prabhu Eswaryadala. Every day he presents one young and beautiful woman. Therefore, the beautiful young women presented to him were running out over time.

Ki Patih Bandeswarya is a symbol of loyalty to Sang Maharaja Sri Eswaryadala, who cannot be separated from one another. It was proven when Ki Patih Bandeswarya thought about his problems because his beautiful woman had run out and only his daughter left, Ni Diah Tantri. Seeing his father Ki Patih Bandeswarya pensive, Ni Diah Tantri approached him and asked what he thought. After Ni Diah Tantri knew her father's difficulties and the wishes of Prabhu Eswaryadala, Ni Diah Tantri was willing to be offered and married to Sang Maharaja Prabhu Eswaryadala. It was until she could awaken him to stop marrying and become aware of his previous behavior.

The teachings of loyalty or Satya have many meanings and intentions contained in the story of Ni Diah Tantri. Satya can be interpreted as faithful, trustworthy, honest, and promises or oaths. Punyatmadja (1996), in the Silakrama book in the Pancasiksa section, the meaning of faithfulness is as follows.

Satya ta kita tan linok

Ring ambek ri wuwus

Ring ulah ring brata,

Sapawekas sang matuha

Translation: 
You are Satya, you do not lie in your thoughts, in your words, in your actions, in brata, and in the parent's advice.

Based on the verse above, Hindu religious teaching as the teachings of loyalty or Satya in the Ni Diah Tantri story can be interpreted as all loyalty. Hence, it plays an essential role in shaping good (suputra) and religious child behavior in the community. According to Sumarni (1994) in Dharma teachings, the Satya aspect is highly exalted. Among all the teachings, Satya is the main and most important. Satya in the story of $\mathrm{Ni}$ Diah Tantri is the most important truth. There are five Satyas in Hinduism, which are known as Panca Satya. It can see as follows.

a. Satya Hredaya means to be faithful to one's mind.

b. Satya Wacana means faithful to the words.

c. Satya Samaya means faithful to the promise

d. Satya Laksana means faithful to the deed

e. Satya Mitra means faitful to friends

Based on the concept of loyalty or Satya teaching, it is expected that people in carrying out their swadharma must adhere to the teachings of Panca Satya: being faithful to thoughts, words, promises, deeds, and friends. Through Panca Satya in the story of Ni Diah Tantri, it explains that the teachings of loyalty are about the loyalty of promises and deeds to friends. Ki Patih Bandeswarya's loyalty to offering a young and beautiful girl to Sang Prabhu Eswaryadala until he sacrificed his daughter. The story of Ni Diah Tantri is Hindu religious teaching of loyalty contained in the story of Ni Diah Tantri. The teaching of loyalty needs to be owned by each individual in accordance with a conscience based on loyalty.

\section{Conclusions}

The Hindu religious teachings contained in the story of Ni Diah Tantri are a form of tendency from the author, which is very useful for readers. Hindu religious teachings in the story of $\mathrm{Ni}$ Diah Tantri consist of the teachings of self-control, especially lust which is influenced by the thoughts of Sang Prabhu Eswaryadala. The next teaching is the teaching of the love of Ni Diah Tantri, who truly sympathizes and her love for her father until Ni Diah Tantri is willing to be handed over to Sang Prabhu Eswaryadala. The last is the loyalty teachings of Ki Patih Bandeswarya to Sang Prabhu Eswaryadala. Ki Patih Bandeswarya's loyalty to Sang Prabhu Eswaryadala was 
manifested by Ki Patih's obedience to the King's orders to offer beautiful girls every day. Therefore, Hindu religious teachings in the story of Ni Diah Tantri are based on loyalty and as a reflection of the social life movement to create a peaceful community.

\section{References}

Aryasa. (1996). Kesusastraan Pengantar Teori dan Sejarah Sastra. Bandung: Angkasa.

Hutomo, S. S. (1991). Mutiara yang Terlupakan: Pengantar Studi Sastra Lisan. Surabaya: HISKI.

Pasek, I M. (2006). Cerita Tantri. Denpasar: Yayasan Dharma Sastra.

Punyatmadja, I. B. O. (1996). Silakrama. Jakarta: Yayasan Dharma Sarati

Sangka (1998). Filsafat Pendidikan dan Dasar Filsafat Pendidikan Pancasila. Surabaya. Usaha Nasional.

Suhardana, K. M. (2007). Tri Kaya Parisuda, Surabaya: Penerbit Paramita.

Sukartha, K., Supartha, N. S., Sandiarta, I M., Wiryani, N. W. (2003). Agama Hindu untuk SLTP Kelas 2, Jakarta: Ganeca Exact.

Sumarni. (1994). Pendidikan Agama Hindu Untuk Kelas V. Bandung : Ganesa Exact.

Sura, I G. (1995). Pengendalian Diri dan Etika Dalam Ajaran Agama Hindu. Jakarta: Hanoman Sakti.

Suweta, I M. (1999). Mahasiswa Hindu dan Perspektif Pemberdayaan Umat. Makalah disampaikan dalam rangka kegiatan Mahasisya Upanayana STAHN Denpasar tanggal 24 Agustus 1999.

Wiryamartana (1990). Arjunawiwaha. Yogyakarta: Duta Wacana University Press. 